\title{
ANALISIS BELANJA TIDAK LANGSUNG KABUPATEN/KOTA DI PROPINSI JAMBI TAHUN 2009-2014
}

\author{
Mila Permata Sari \\ Program Studi Keuangan Daerah FEB Universitas Jambi \\ bibicek261@gmail.com
}

\begin{abstract}
Abstrak
Penelitian ini bertujuan untuk mengetahui dan menganalisis perlembangan belanja tidak langsung Kabupaten/Kota di Provinsi Jambi tahun 2009-2014. Selain itu juga untuk mengetahui dan menganalisis efisiensi belanja tidak langsung dari sisi Efisiensi Kabupaten/Kota di Provinsi Jambi 2009-2014.Teknis analisis yang digunakan yaitu analisis kualitatif dan kuantitatif, Analisis Alokasi Belanja terhadap perkembangan belanja tidak langsung, Analisis kinerja belanja dari sisi efisiensi. Perkembangan belanja tidak langsung kabupaten/kota di provinsi Jambi tahun 2009-2014 berdasarkan Rata-rata per tahun yakni tertinggi pada kabupaten Bungo sebesar $1.19 \%$ dan terendah pada kabupaten Tanjung Jabung Timur sebesar $0.11 \%$. Berdasarkan efisiensi belanja tidak langsung kabupaten/kota di provinsi Jambi pada tahun 2009-2014 dari rata- rata belanja tidak langsung target dari tahun ke tahun sudah mengalami peningkatan karena dari tahun 2009-2014 seluruh kabupaten sudah efisien dari tahun ke tahun dalam mengelola belanja tidak langsung Kabupaten/Kota Di Provinsi Jambi pada Kota Sungai Penuh sudah sangat efektif dari Efisiensi Belanja Tidak Langsung
\end{abstract}

Kata Kunci; Tingkat Perkembangan, Efisiensi Belanja Tidak Langsung

\begin{abstract}
This study aims to identify and analyze the development of indirect spending in districts / cities in Jambi Province in 2009-2014. In addition, it is also used to determine and analyze the efficiency of indirect spending in terms of district / municipal efficiency in Jambi Province 2009-2014. The technical analysis used is qualitative and quantitative analysis, analysis of expenditure allocation on indirect spending development, analysis of spending performance in terms of efficiency. The development of district / municipal indirect spending in Jambi province in 2009-2014 was based on the annual average, namely the highest in Bungo district at 1.19\% and the lowest in Tanjung Jabung Timur district at $0.11 \%$. Based on the efficiency of district / municipal indirect spending in Jambi province in 2009-2014, the average target indirect expenditure from year to year has increased because from 2009-2014 all districts have been efficient from year to year in managing indirect expenditure. Districts / Cities in Jambi Province in Sungai Penuh City have been very effective from the efficiency of indirect spending.
\end{abstract}

Keywords; Level of Development, Efficiency of Indirect Shopping

\section{PENDAHULUAN}

Indonesia merupakan negara yang sedang melaksanakan pembangunan pada segala bidang, dalam hal ini pembangunan yang dilaksanakan secara merata di seluruh tanah air diupayakan dapat di manfaatkan oleh masyarakat dalam upaya peningkatan kualitas manusia dan masyarakat Indonesia yang dilakukan secara global. Dalam pelaksanaan mengacu pada kepribadian bangsa dan nilai luhur yang universal untuk mewujudkan kehidupan bangsa yang berdaulat, mandiri sejahtera, maju dan kukuh moral dan etika yang 
ditujukan untuk memperbaiki taraf kesejahteraan secara luas.

Perkembangan yang hanya mengutamakan pertumbuhan ekonomi serta tidak diimbangi dengan kehidupan sosial politik, ekonomi yang demokratis berkeadilan. Bertitik tolak terhadap fundamental pembangunan ekonomi yang rapuh dan penyelenggaraan negara yang sangat birokrat dan cenderung mengutamakan kepentingan pribadi, dan pengelolaan sumber daya alam yang tidak terkendali yang pada akhirnya akan menyebalkan terjadinya krisis moneter dan ekonomi. Dengan demikian hal tersebut merupakan penyebab utama terjadinya krisis moral yang memperhatikan dan timbulnya krisis nasional yang berkelanjutan

Belanja daerah dalam penyusunan anggaran sewajarnya berorientasi kepada publik besarnya alokasi anggaran yang berorientasi kepada kepentingan masyarakat .Pengalokasian anggaran yang lebih mengutamakan kepada kepentingan masyarakat akan tergambar dalam proporsi pengalokasian anggaran yang lebih besar pada biaya pelayanan yang dapat dinikmati antara pemerintah daerah dan SKPD merupakan amanat rakyat. Ini adalah tantangan untuk mewujudkan bahwa sebagai pihak yang bertanggung jawab akan kepentingan rakyat pemerintah daerah atau DPRD harus memposisikan dirinya pada posisi yang tepat.

Pengelolaan belanja daerah dilaksanakan berdasarkan pada anggaran (perpormance budget) yaitu belanja daerah yang berorientasi pada pencapaian hasil atau mencerminkan efisiensi dan efektivitas pelayanan publik ,yang berarti belanja daerah harus berorientasi pada pelayanan publik. Oleh karena itu arah pengelolaan belanja daerah harus di gunakan sebesar-besarnya untuk kepentingan publik terutama masyarakat miskin dan kurang beruntung (pro-poor), pertumbuhan ekonomi (pro-job)serta menjaga kelestarian dan berlanjutan lingkungan (pro-environment).

Mulai tahun 2010 struktur belanja di pilah dan di belanjakan atas belanja tidak langsung dan belanja langsung, sebagai mana di atur dalam peraturan menteri dalam negeri No.59 Tahun 2007 tentang pedoman pengelolaan keuangan daerah .menurut Nurlan (2009) belanja daerah ,meliputi semua pengeluaran dari kas rekening kas umum daerah yang mengurangi ekuitas dana lancar, yang merupakan kewajiban daerah dalam satu tahun anggaran yang tidak akan diperoleh pembayarannya kembali oleh daerah .belanja belanja daerah di rinci menurut urusan daerah, pungsi, organisasi, program, kegiatan, kelompok dan jenis belanja. Belanja daerah digunakan dalam rangka mendanai pelaksanaan urusan pemerintah yang menjadi kewenangan kabupaten/kota terdiri dari urusan wajib, urusan pilihan dan urusan yang penanganannya dalam bidang tertentu yang dapat dilaksanakan bersama antara pemerintah pusat dan pemerintah daerah. Belanja penyelenggaraan urusan wajib untuk melindungi dan meningkatkan kualitas kehidupan masyarakat dalam upaya memenuhi kewajiban daerah yang di wujudkan dalam bentuk peningkatan pelayanan publik.

Dalam rangka memudahkan penilaian kewajaran biaya sesuatu program atau kegiatan, belanja menurut kelompok terdiri dari belanja tidak langsung dan belanja langsung. Menurut Rintonga (2009) belanja tidak langsung merupakan belanja yang tidak memiliki keterkaitan secara tidak langsung dengan pelaksanaan program dan kegiatan, yang terdiri dari belanja pegawai, belanja bunga, subsidi, hibah, bantuan sosial, belanja bagi hasil, bantuan keuangan dan belanja tidak terduga. Sedangkan belanja langsung merupakan belanja yang memiliki keterkaitan secara langsung dengan program dan kegiatan yang meliputi belanja pengawai, belanja barang, dan jasa serta belanja modal.

Belanja daerah dalam APBD kabupaten/kota di propinsi Jambi meliputi belanja tidak langsung terdiri dari belanja pengawai, belanja bunga, belanja subsidi, belanja hibah, 
belanja bantuan sosial, belanja bagi hasil bantuan keuangan dan belanja tidak terduga.

\section{Tujuan Penelitian}

1. Untuk mengetahui dan menganalisis perkembangan belanja tidak langsung kabupaten/kota propinsi Jambi tahun 2009-2014.

2. Untuk mengetahui dan menganalisis efektivitas belanja tidak langsung kabupaten/kota propinsi Jambi 2009-2014

\section{METODE PENELITIAN}

\section{Pendekatan Penelitian}

Penelitian ini merupakan pendekatan analisis deskriptif dengan metode pengelompokan data secara kualitatif untuk menganalisis dan membandingkan alokasi belanja daerah. Penelitian ini merumuskan diri pada pengajian mengenai analisis alokasi anggaran belanja pelayanan publik.

\section{Jenis Dan Sumber Data Jenis Data}

Jenis data dapat di gunakan dalam penelitian ini adalah data sekunder yang diperoleh dari berbagai sumber internal maupun eksternal. data internal adalah data yang berasal dari organisasi di mana penelitian dilakukan, yaitu dari anggaran pendapatan dan belanja daerah (APBD) kabupaten/kota propinsi Jambi. Sedangkan data eksternal adalah data yang berasal dari badan pusat statistik (BPS) kabupaten kota propinsi Jambi.

\section{Sumber Data}

Sumber data yang digunakan dalam penulisan skripsi ini bersumber dari realisasi anggaran pendapatan dan belanja daerah kabupaten/kota propinsi Jambi dan juga menggunakan data yang bersumber dari supe literatur dan penelitian- penelitian yang dilakukan sebelumnya serta studi pustaka.

\section{Metode Pengumpulan Data}

a. Studi kepustakaan, di gunakan untuk meneliti mengkaji berbagai bahan dokumentasi yang berkaitan dengan judul, topik, dan pendekatan peneliti tentang desentralisasi fiskal dan alokasi anggaran belanja tidak langsung juga mendapatkan pijakan berupa dasar peraturan dan kebijakan yang relevan ,serta arah teorinya dari peneliti-peneliti sebelumnya .

b. Dokumentasi, digunakan untuk menelusuri data-data dokumen belanja pelayanan publik dan penganggaran, terutama yang terkait dengan pokok penelitian, yang di peroleh dari berbagai instansi.

\section{Metode Analisis Data}

Metode analisis data yang digunakan dalam penelitian adalah metode deskriptif kualitatif. Untuk melihat perkembangan APBD dan alokasi belanja pelayanan publik di kabupaten/kota propinsi Jambi tahun anggaran 2010-2014

Adapun alat analisis yang di gunakan dalam penulisan skripsi ini :

a. Untuk menghitung perkembangan anggaran dan belanja tidak langsung(Halim 2010) dapat menggunakan rumus:

$$
\mathrm{R}=\frac{B T L n-B T L n-1}{B T L n-1} \times 100
$$


Ket:

$\mathrm{R}=$ Perkembangan

Btl $\mathrm{t} \quad=$ Tahun sekarang

Btl $\mathrm{t}-1$ = Btl tahun sebelumnya

b. Untuk menjawab tujuan yang ke dua yaitu efisiensi belanja dan belanja tidak langsung terhadap APBD daerah menggunakan rumus Mahmudi (2010) setelah dimodifikasi :

Efisiensi belanja tidak langsung terhadap APBD

$$
\text { EFISIENSI } \frac{\text { Realisasi Belanja Langsung }}{\text { Anggran Belanja Langsung }} \times 100
$$

Ket:

Efisiensi BTL $=$ Efisiensi belanja tidak langsung

RBL $\quad=$ Realisasi belanja tidak langsung

RPD $\quad=$ Anggaran belanja tidak langsung

Kriteria Efisiensi menurut pemendagri No.690.900-327 yang di kutip Yulia Anggaran Sari (2010) adalah sebagai berikut:

a. Lebih dari $100 \%$ = sangat efisien

b. $90 \%-100 \%=$ Efisiensi

c. $80 \%-90 \%=$ cukup efektif

d. $60 \%-80 \%=$ kurang efisien

e. Kurang dari sama dengan $60 \%=$ tidak efisien

\section{HASIL DAN PEMBAHASAN}

\section{Perkembangan Belanja Tidak Langsung Kabupaten/Kota Di Provinsi Jambi}

Apabila dilihat secara geografis kondisi wilayah kabupaten/kota memiliki sumber dan potensi yang cukup besar untuk menunjukkan pendapatan asli daerah (PAD) sebagai mana yang telah di tentukan dalam undang-undang No.32 2004 tentang pemerintah daerah yang telah di atur sebagai jenis penerimaan daerah yang terhimpun dalam pendapatan asli daerah (PAD) yang meliputi hasil retribusi daerah, hasil pengelolaan kekayaan daerah yang dipisahkan dan lain-lain pendapatan asli daerah.

Perkembangan belanja tidak langsung kabupaten/kota di Provinsi Jambi Merupakan belanja untuk kegiatan yang sifatnya tidak biasa atau tidak di harapkan berulang seperti penanggulangan bencana alam atau bencana sosial yang tidak diperkirakan sebelumnya, termasuk pengembalian atas kelebihan penerimaan daerah tahun sebelumnya yang telah tertutup.

Penganggaran belanja tidak langsung sebagai mana di atur pada pasal 97 ayat (2) peraturan menteri dalam Negeri No.13 Tahun 2006 tentang pedoman pengelolaan keuangan daerah menyatakan belanja bunga, belanja subsidi,belanja hibah, belanja bantuan sosial, belanja bagi hasil dan belanja bantuan tidak terduga hanya dianggarkan dalam RKA pada satuan kerja pengelolaan keuangan daerah (SKPKD), sehingga pada SKPD lainnya dalam RKA SKPD untuk belanja tidak langsung ,hanya menganggarkan belanja pegawai. 
Tabel 1. Perkembangan Belanja Tidak Langsung Kabupaten Batang Hari

\begin{tabular}{|c|c|c|}
\hline Tahun & Anggaran & Perkembangan (\%) \\
\hline 2010 & 184.207 & -3897 \\
\hline 2011 & 363.468 & 91.07 \\
\hline 2012 & 351.968 & 3.26 \\
\hline 2013 & 451.604 & 24.2 \\
\hline 2014 & 499.278 & 10.55 \\
\hline & Rata-rata & $\mathbf{4 5 0 . 5 5}$ \\
\hline
\end{tabular}

Sumber :statistik keuangan daerah provinsi Jambi 2013

Berdasrkan tabel 1 Perkembangan belanja tidak langsung kabupaten batang hari pada tahun 2009-2010 pemerintah Kabupaten Batang hari kontribusi belanja tidak langsung pada tahun 2010 perkembangan belanja tidak langsung sebesar $-38.91 \%$ dan mengalami peningkatan pada tahun 2011 sebesar 91,07\% bahkan persentase tahun 2012 juga mengalami penurunan sebesar $3.26 \%$ dan pada tahun selanjutnya juga mengalami penurunan seperti tahun 2013 jumlah anggaran belanja tidak langsung sebesar $24.2 \%$ dan pada tahun 2014 juga mengalami penurunan sebesar $10.55 \%$ rata-rata persentase dari tahun 2009-2014 sebesar 450.55\% .

Tabel 2. Perkembangan Belanja Tidak Langsung Kabupaten Bungo

\begin{tabular}{|c|c|c|}
\hline Tahun & Anggaran & Perkembangan (\%) \\
\hline 2010 & 184.207 & 37,87 \\
\hline 2011 & 395.329 & 114.61 \\
\hline 2012 & 435.377 & 10.13 \\
\hline 2013 & 539.160 & 23.83 \\
\hline 2014 & 588.988 & 9.24 \\
\hline \multicolumn{2}{|c|}{ Rata-rata } & $\mathbf{3 9 . 1 3 6}$ \\
\hline
\end{tabular}

Sumber :statistik keuangan daerah provinsi Jambi 2013

Berdasarkan tabel 2 Perkembangan belanja tidak langsung kabupaten Bungo pada tahun 2010 sebesar $37.87 \%$ pada tahun 2011 mengalami peningkatan sebesar $114.61 \%$ pada tahun 2012 persentase belanja kabupaten Bungo mengalami penurunan sebesar 10.13\% dan pada tahun 2013 mengalami peningkatan sebesar $23.83 \%$ dan pada tahun 2014 mengalami penurunan sebesar $9.24 \%$ dari perkembangan belanja tidak langsung kabupaten Bungo mengalami peningkatan penurunan dan peningkatan yang tidak terlalu jauh dan rata-rata dari tahun 2009-2014 sebesar 39.136\%. 
Tabel 3. Perkembangan Belanja Tidak Langsung

Kabupaten Kerinci

\begin{tabular}{|c|c|c|}
\hline Tahun & Anggaran & Perkembangan (\%) \\
\hline 2010 & 184.207 & 46,18 \\
\hline 2011 & 352.022 & 91.10 \\
\hline 2012 & 334.652 & 4.93 \\
\hline 2013 & 394.656 & 15.63 \\
\hline 2014 & 399.263 & 1.16 \\
\hline \multicolumn{2}{|c|}{ Rata-rata } & $\mathbf{3 1 . 8}$ \\
\hline
\end{tabular}

Sumber :statistik keuangan daerah provinsi Jambi 2013

Berdasarkan tabel 3 perkembangan belanja tidak langsung kabupaten Kerinci pada tahun 2009-2014 persentase perkembangan belanja tidak langsung kabupaten Kerinci tahun 2010 sebesar $46.18 \%$ dan pada tahun 2011 mengalami peningkatan sebesar $91.10 \%$ dan pada tahun 2012 mengalami penurunan sebesar $4.93 \%$ dan pada tahun 2013 mengalami peningkatan sebesar $15.63 \%$ dan pada tahun 2014 perkembangan belanja tidak langsung kembali mengalami penurunan sebesar 1.16\% dan rata-rata dari tahun 2009-2014 sebesar $31.8 \%$.

Tabel 4. Perkembangan Belanja Tidak Langsung Kabupaten Merangin

\begin{tabular}{|c|c|c|}
\hline Tahun & Anggaran & Perkembangan (\%) \\
\hline 2010 & 322.259 & 16.74 \\
\hline 2011 & 313.933 & 2.58 \\
\hline 2012 & 386.649 & 23.16 \\
\hline 2013 & 447.625 & 15.77 \\
\hline 2014 & 547.465 & 22.30 \\
\hline \multicolumn{2}{|c|}{ Rata-rata } & $\mathbf{1 6 . 0 4 4}$ \\
\hline
\end{tabular}

Sumber :statistik keuangan daerah provinsi Jambi 2013

Berdarkan tabel 4 perkembangan belanja tidak langsung kabupaten Merangin tahun anggaran 2009-2014 perkembangan belanja tidak langsung kabupaten Merangin pada tahun 2010 sebesar $16.74 \%$ dan pada tahun 2011 mengalami penurunan sebesar $2.58 \%$ dan pada tahun 2012 mengalami peningkatan sebesar $23.16 \%$ pada tahun 2013 persentase perkembangan belanja mengalami penurunan sebesar $15.77 \%$ dan pada tahun 2014 mengalami peningkatan sebesar $22.30 \%$ dan rata-rata perkembangan tahun 2009-2014 sebesar $14.044 \%$.

Tabel 5. Perkembangan Belanja Tidak Langsung Kabupaten Muaro Jambi

\begin{tabular}{|c|c|c|}
\hline Tahun & Anggaran & Perkembangan (\%) \\
\hline 2010 & 329.819 & 19.03 \\
\hline 2011 & 397.764 & 20.60 \\
\hline 2012 & 365.044 & -8.22 \\
\hline 2013 & 412.536 & 13.00 \\
\hline 2014 & 490.845 & 18.98 \\
\hline \multicolumn{2}{|c|}{ Rata-rata } & $\mathbf{5 3 . 4 9}$ \\
\hline
\end{tabular}

Sumber :statistik keuangan daerah provinsi Jambi 2013 
Berdarkan tabel 5 perkembangan belanja tidak langsung kabupaten Muaro Jambi tahun 2009-2014 persentase belanja tidak langsung tahun 2010 sebesar $19.03 \%$ pada tahun 2011 mengalami peningkatan sebesar $20.60 \%$ dan pada tahun 2012 perkembangan belanja mengali penurunan sebesar $-8.22 \%$ dan pada tahun 2013 kembali mengalami peningkatan sebesar $13.00 \%$ dan pada tahun 2014 persentase perkembangan belanja mengalami peningkatan sebesar $18.98 \%$ dan rata-rata persentase belanja tidak langsung sebesar $53.49 \%$

Tabel 6. Perkembangan Belanja Tidak Langsung Kabupaten Sarolangun

\begin{tabular}{|c|c|c|}
\hline Tahun & Anggaran & Perkembangan (\%) \\
\hline 2010 & 273.825 & 28.50 \\
\hline 2011 & 315.171 & 15.10 \\
\hline 2012 & 323.883 & -2.76 \\
\hline 2013 & 367.233 & 13.38 \\
\hline 2014 & 413.322 & 12.55 \\
\hline \multicolumn{2}{|c|}{ Rata-rata } & $\mathbf{1 3 . 3 5 4}$ \\
\hline
\end{tabular}

Sumber :statistik keuangan daerah provinsi Jambi 2013

Berdarkan tabel 6 Perkembangan belanja tidak langsung kabupaten Sarolangun tahun 2009-2014 pada tahun 2010 perkembangan belanja tidak langsung sebesar $28.50 \%$ pada tahun 2011 mengalami penurunan sebesar $15.10 \%$ pada tahun 2012 mengalami penurunan sebesar-2.76\% dan tahun 2013 mengalami peningkatan sebesar $13.38 \%$ dan tahu 2014 juga mengalami penurunan sebesar $12.55 \%$ dan rata-rata perkembangan belanja tidak langsung sebesar 2009-2014 sebesar $13.354 \%$.

Tabel 7. Perkembangan Belanja Tidak Langsung Kabupaten Tanjung Jabung Barat

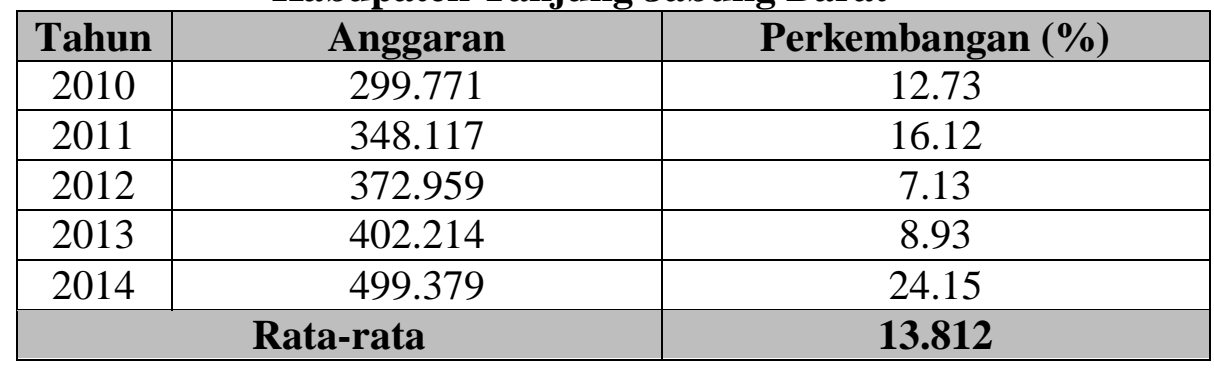

Sumber :statistik keuangan daerah provinsi Jambi 2013

Dari tabel 7 perkembangan belanja tidak langsung kabupaten tanjung Jabung barat perkembangan belanja tidak langsung tahun 2010 sebesar $12.73 \%$ erkembangan belanja tidak langsung tahun 2011 mengalami peningkatan sebesar $16.12 \%$ dan pada tahun 2012 menurun sebesar $7.13 \%$ dan tahun 2013 persentase belanja tidak langsung mengalami kenaikan sebesar 8.93\% dan pada tahun 2014 perkembangan belanja tidak langsung mengalami peningkatan sebesar $24.15 \%$ dan rata- rata perkembangan belanja tidak langsung sebesar $13.812 \%$. 
Tabel 8. Perkembangan Belanja Tidak Langsung Kabupaten Tanjung Jabung Timur

\begin{tabular}{|c|c|c|}
\hline Tahun & Anggaran & Perkembangan (\%) \\
\hline 2010 & 269.258 & 33.26 \\
\hline 2011 & 277.042 & 2.89 \\
\hline 2012 & 305.433 & 10.24 \\
\hline 2013 & 322.880 & 5.40 \\
\hline 2014 & 341.809 & 5.86 \\
\hline \multicolumn{2}{|c|}{ Rata-rata } & $\mathbf{5 1 . 8 5}$ \\
\hline \multicolumn{2}{|c|}{ Sumber :statistik keuangan daerah provinsi Jambi 2013}
\end{tabular}

Berdasarkan tabel 8 perkembangan belanja tidak langsung kabupaten tanjung Jabung timur pada tahun 2010 sebesar $33.26 \%$ dan pada tahun 2011 mengalami penurunan sebesar $2.89 \%$ dan pada tahun 2012 kembali meningkat yakni sebesar $10.24 \%$ dan pada tahun 2013 mengalami penurunan sebesar $5.40 \%$ dan tahun 2014 mengalami penurunan sebesar $5.40 \%$ dan rata - rata perkembangan belanja tidak langsung kabupaten Tanjung Jabung Timur yakni sebesar 51.85\%.

Tabel 9. Perkembangan Belanja Tidak Langsung Kabupaten Tebo

\begin{tabular}{|c|c|c|}
\hline Tahun & Anggaran & Perkembangan(\%) \\
\hline 2010 & 210.472 & 13.69 \\
\hline 2011 & 267.974 & 27.25 \\
\hline 2012 & 294.921 & 10.05 \\
\hline 2013 & 341.223 & 15.69 \\
\hline 2014 & 362.148 & 6.13 \\
\hline \multicolumn{2}{|c|}{ Rata-rata } & $\mathbf{1 4 . 5 6 2}$ \\
\hline
\end{tabular}

Sumber :statistik keuangan daerah provinsi Jambi 2013

Berdasarkan tabel 9 Perkembangan Belanja Tidak Langsung Kabupaten Tebo tahun 2009-2014 perkembangan belanja tahun 2010 sebesar $13.69 \%$ dan pada tahun 2011 mengalami peningkatan sebesar 27.25\% saat tahun 2012 persentase perkembangan mengalami penurunan sebesar $10.05 \%$ dan juga pada tahun 2013 juga mengalami penurunan sebesar $15.63 \%$ dan pada tahun 2014 mengalami peningkatan $6.13 \%$ yakni sebesar $0.06 \%$ dan rata-rata perkembangan belanja tidak langsung kabupaten Tebo sebesar $14.562 \%$.

Tabel 10. Perkembangan Belanja Tidak Langsung

Kota Jambi

\begin{tabular}{|c|c|c|}
\hline Tahun & Anggaran & Perkembangan(\%) \\
\hline 2010 & 433.262 & 16.25 \\
\hline 2011 & 489.881 & 13.06 \\
\hline 2012 & 534.561 & 9.12 \\
\hline 2013 & 638.773 & 16.31 \\
\hline 2014 & 676.597 & 5.92 \\
\hline \multicolumn{2}{|c|}{ Rata-rata } & $\mathbf{1 2 . 1 3 2}$ \\
\hline
\end{tabular}

Sumber :statistik keuangan daerah provinsi Jambi 2013 
Berdasarka tabel 10 Perkembangan Belanja Tidak Langsung Kota Jambi Tahun 2009-2014 perkembangan belanja tidak langsung kota Jambi pada tahun 2010 sebesar 13.25\% dan pada tahun 2011 mengalami peningkatan yakni sebesar $13.06 \%$ pada tahun 2012 persentase belanja tidak langsung sebesar 9.12\% mengalami penurunan dan pada tahu 2013 mengalami peningkatan sebesar 16.31\% dan pada tahun 2014 perkembangan mengalami penurunan kembali sebesar $5.92 \%$ dan rata - rata perkembangan belanja tidak langsung kota Jambi sebesar $12.132 \%$.

Tabel 11. Perkembangan Belanja Tidak Langsung

Kota Sungai Penuh

\begin{tabular}{|c|c|c|}
\hline Tahun & Anggaran & Perkembangan (\%) \\
\hline 2010 & 184.207 & 165.76 \\
\hline 2011 & 219.598 & 19.21 \\
\hline 2012 & 229.977 & 4.72 \\
\hline 2013 & 264.044 & 12.90 \\
\hline 2014 & 291.621 & 10.44 \\
\hline \multicolumn{2}{|c|}{ Rata-rata } & $\mathbf{4 2 . 6 0 6}$ \\
\hline
\end{tabular}

Sumber :statistik keuangan daerah provinsi Jambi 2013

Berdasarkan tabel 11. Perkembangan Belanja Tidak Langsung Kota Sungai Penuh Tahun 2009-2014 perkembangan belanja tidak langsung tahun 2010 sebesar $165.76 \%$ dan pada tahun 2011 mengalami penurunan yakni sebesar 19.21\% dan juga pada tahun 2012 juga mengalami penurunan yang sangat rendah yakni sebesar 4,72\% dan pada tahun 2013 perkembangan belanja tidak langsung sebesar $12.90 \%$ dan pada tahun 2014 persentase mengalami penurunan sebesar $10.44 \%$ dan rata-rata perkembangan kota sungai penuh tahun 2009-2014 sebesar 42.606\%.

\section{Efisiensi Belanja Tidak Langsung Kab/Kota Di Provinsi Jambi Tahun 2009-2014}

Tabel 12. Efisiensi Belanja Tidak Langsung Kabupaten Batang Hari

\begin{tabular}{|c|c|c|c|c|}
\hline Tahun & Target & Realisasi & $(\%)$ & Efisiensi \\
\hline 2009 & 301.883 & 301823 & 99,980 & Efisiensi \\
\hline 2010 & 184.207 & 184187 & 99,989 & Efisiensi \\
\hline 2011 & 351.968 & 351948 & 99,994 & Efisiensi \\
\hline 2012 & 363.468 & 363448 & 99,994 & Efisiensi \\
\hline 2013 & 451.604 & 451584 & 99,995 & Efisiensi \\
\hline 2014 & 499.278 & 499258 & 99,995 & Efisiensi \\
\hline \multicolumn{3}{|c|}{ Rata-rata } & 99,93 & Efisiensi \\
\hline
\end{tabular}

Sumber :statistik keuangan daerah provinsi Jambi 2013

Berdasarkan tabel 12 Efisiensi belanja tidak langsung kabupaten Batang Hari pencapainya target realisasi sudah mengalami Efisiensi dari tahun 2009-2014 dan rata-rata sebesar $99.93 \%$ dan pada tahun 2009 capaian sebesar $99.980 \%$ pada tahun 2010 sebesar 99,989\% pencapaian target realisasi dan pada tahun 2011 sebesar $99,994 \%$ dan pada tahun 2012 juga sudah Efisiensi karena mengalami kesamaan pada tahun 2013 yakni sebesar $99.994 \%$ dan pada tahun 2013 da 2014 Efisiensi belanja tidak langsung kabupaten Batang 
Hari sebesar $99.995 \%$.

Tabel 13. Efisiensi Belanja Tidak Langsung Kabupaten Bungo

\begin{tabular}{|c|c|c|c|c|}
\hline Tahun & Target & Realisasi & $\mathbf{( \% )}$ & Efisiensi \\
\hline 2009 & 296.515 & 296495 & 99,999 & Efisiensi \\
\hline 2010 & 184.329 & 184309 & 99,989 & Efisiensi \\
\hline 2011 & 395.160 & 395140 & 99,994 & Efisiensi \\
\hline 2012 & 435.377 & 435357 & 99,995 & Efisiensi \\
\hline 2013 & 539.160 & 539140 & 99,996 & Efisiensi \\
\hline 2014 & 588.988 & 588968 & 99,996 & Efisiensi \\
\hline \multicolumn{5}{|c|}{ Rata-rata } \\
\hline
\end{tabular}

Sumber :statistik keuangan daerah provinsi Jambi 2014

Realisasi belanja tidak langsung Kabupaten Bungo realisasi target belanja tidak langsung tahun 2009-2014 target belanja tidak langsung sudah mengalami efisien dari tahun ke tahun seperti tahun 2009 target realisasi pada tahun ini sebesar 99.999\% dan mengalami penurunan pada tahun 2010 sebesar 99.989\% setiap tahun mengalami perubahan setiap pencapaian target pada tahun 2011 sebesar $99.994 \%$ dan pada tahun berikutnya sebesar $99.996 \%$ pada tahun 2012 dan pada tahun 2013-2014 realisasi belanja tidak langsung mengalami pencapainya target yang sama yaitu sebesar $99.996 \%$ dan rata pencapainya efisiensinya sebesar $99.94 \%$.

Tabel 14. Realisasi Belanja Tidak Langsung Kabupaten Kerinci

\begin{tabular}{|c|c|c|c|c|}
\hline Tahun & Target & Realisasi & $\mathbf{( \% )}$ & Efisiensi \\
\hline 2009 & 342,292 & 342272 & 94,16 & Efisiensi \\
\hline 2010 & 184.207 & 184187 & 99,989 & Efisiensi \\
\hline 2011 & 352.022 & 352002 & 99,994 & Efisiensi \\
\hline 2012 & 334.652 & 334632 & 99,994 & Efisiensi \\
\hline 2013 & 394.656 & 394.636 & 99,994 & Efisiensi \\
\hline 2014 & 399.263 & 399.243 & 99,994 & Efisiensi \\
\hline \multicolumn{3}{|c|}{ Rata-rata } & $\mathbf{9 9 . 9 4}$ & Efisiensi \\
\hline
\end{tabular}

Sumber :statistik keuangan daerah provinsi Jambi 2013

Berdasarkan tabel 14 Efisien Belanja Tidak Langsung Kabupaten Kerinci pencapainya target realisasi sudah mengalami Efisien dari Tahun 2009- 2014 dan rata-rata sebesar 99,16\% dan pada tahun 2009 capaian sebesar $99.980 \%$ pada tahun 2010 sebesar 99.989\% pencapaian target realisasi dan pada tahun 2011 sebesar 99,994\% dan pada tahun 2012 juga sudah Efisien karena mengalami kesamaan pada tahun 2013 yakni sebesar 99.994\% dan pada tahun 2013 dan 2014 Efisien belanja tidak langsung kabupaten batang hari sebesar $99.994 \%$. 
Tabel 15. Efisien Belanja Tidak Langsung Kabupaten Merangin

\begin{tabular}{|c|c|c|c|c|}
\hline Tahun & Target & Realisasi & $(\mathbf{\% )}$ & Efisiensi \\
\hline 2009 & 276,029 & 276009 & 99.754 & Efisiensi \\
\hline 2010 & 322.259 & 322239 & 99,993 & Efisiensi \\
\hline 2011 & 313.933 & 313923 & 99,996 & Efisiensi \\
\hline 2012 & 386.649 & 386629 & 99.827 & Efisiensi \\
\hline 2013 & 447.625 & 447605 & 99,995 & Efisiensi \\
\hline 2014 & 547.465 & 547445 & 99,996 & Efisiensi \\
\hline \multicolumn{5}{|c}{ Rata-rata } \\
\hline \multicolumn{5}{|c|}{ Sumber :statistik keuangan daerah provinsi Jambi 2013} \\
\hline
\end{tabular}

Efisien belanja tidak langsung kabupaten Merangin pencapainya target realisasinya pada tahun 2009-2014 setiap tahunnya mengalami perubahan dan pada tahun 2009 efisien belanja tidak langsung kabupaten batang hari sebesar $99.754 \%$ pada tahun 2010 sudah efisien juga dengan anggaran sebesar 99,993\% dan pada tahun 2011 sebesar $99.996 \%$ pada tahun 2012 sudah efisien juga yakni sebesar $94.827 \%$ dan pada tahun 2013 efisien sebesar $99.995 \%$ dan begitu juga pada tahun 2014 efisiennya sudah efisien juga yakni sebesar $99.996 \%$ dan rata- rata per tahun dari tahun 2009-2014 yakni sebesar $99.96 \%$.

Tabel 16. Efisien Belanja Tidak Langsung Kabupaten Muaro Jambi

\begin{tabular}{|c|c|c|c|c|}
\hline Tahun & Target & Realisasi & $(\%)$ & Efisiensi \\
\hline 2009 & 277.071 & 277051 & 99,992 & Efisiensi \\
\hline 2010 & 329.819 & 329799 & 99,993 & Efisiensi \\
\hline 2011 & 397.764 & 397761 & 99,999 & Efisiensi \\
\hline 2012 & 365.044 & 365024 & 99,994 & Efisiensi \\
\hline 2013 & 412.536 & 412516 & 99,995 & Efisiensi \\
\hline 2014 & 490.845 & 490825 & 99,995 & Efisiensi \\
\hline \multicolumn{3}{|c|}{ Rata-rata } & 99.994 & Efisiensi \\
\hline
\end{tabular}

Sumber :statistik keuangan daerah provinsi Jambi 2013

Realisasi Belanja Tidak Langsung Kabupaten Muaro Jambi realisasi target belanja tidak langsung tahun 2009-2014 target belanja tidak langsung sudah mengalami EFISIEN dari tahun ke tahun seperti tahun 2009 target realisasi pada tahun ini sebesar 99.992\% dan mengalami penurunan pada tahun 2010 sebesar $99.999 \%$ setiap tahun mengalami perubahan setiap pencapaian target pada tahun 2011 sebesar $99.993 \%$ dan pada tahun berikutnya sebesar $99.995 \%$ pada tahun 2012 dan pada tahun 2013-2014 realisasi belanja tidak langsung mengalami pencapainya target yang sama yaitu sebesar $99.995 \%$ dan rata pencapainya Efisien nya sebesar $99.994 \%$. 
Tabel 17. Efisien Belanja Tidak Langsung

Kabupaten Sarolangun

\begin{tabular}{|c|c|c|c|c|}
\hline Tahun & Target & Realisasi & $(\%)$ & Efisiensi \\
\hline 2009 & 213.088 & 213068 & 99,990 & Efisiensi \\
\hline 2010 & 273.825 & 273805 & 99,992 & Efisiensi \\
\hline 2011 & 315.171 & 315151 & 99,993 & Efisiensi \\
\hline 2012 & 323.883 & 323863 & 99,993 & Efisiensi \\
\hline 2013 & 367.233 & 367213 & 99,994 & Efisiensi \\
\hline 2014 & 413.322 & 413302 & 99,995 & Efisiensi \\
\hline \multicolumn{3}{|c|}{ Rata-rata } & 99.993 & Efisiensi \\
\hline
\end{tabular}

Sumber :statistik keuangan daerah provinsi Jambi 2013

Efisien Belanja Tidak Langsung Kabupaten Sarolangun pada tahun 2009-2014 Efisien target realisasi belanja dari tahun ke tahun sudah mengalami efisien dan dapat kita lihat dari tahun ke tahun yakni sepeti tahun 2009 Efisien nya sudah mengalami efisien yakni sebesar $99.990 \%$ dan tahun 2010 sudah efisien juga yakni sebesar $99.992 \%$ dan pada tahun 2011-2012 pencapainya efisiensinya sama besar yaitu sebesar $99.993 \%$ pada tahun 2013 dan tahun 2014 tidak begitu mengalami perubahan yakni $99.994 \%$ dan 99.995 $\%$ dan rata-rata efisiensinya sebesar $99.993 \%$ dari tahun ke tahun.

Tabel 18. Efisien Belanja Tidak Langsung Kabupaten

Tanjung Jabung Barat

\begin{tabular}{|c|c|c|c|c|}
\hline Tahun & Target & Realisasi & $(\%)$ & Efisiensi \\
\hline 2009 & 265.899 & 265870 & 99,989 & Efisiensi \\
\hline 2010 & 299.771 & 299751 & 99,993 & Efisiensi \\
\hline 2011 & 348.117 & 348097 & 99.254 & Efisiensi \\
\hline 2012 & 372.959 & 372939 & 99.637 & Efisiensi \\
\hline 2013 & 402.214 & 402194 & 99,995 & Efisiensi \\
\hline 2014 & 499.379 & 499359 & 99,995 & Efisiensi \\
\hline \multicolumn{3}{|c|}{ Rata-rata } & 99.995 & Efisiensi \\
\hline
\end{tabular}

Sumber :statistik keuangan daerah provinsi Jambi 2013

Efisiensi Belanja Tidak Langsung Kabupaten Tanjung Jabung Timur pencapainya target realisasinya pada tahun 2009-2014 setiap tahunnya mengalami perubahan dan pada tahun 2009 efisiensi belanja tidak langsung kabupaten batang hari sebesar $99.989 \%$ pada tahun 2010 sudah efisien juga dengan anggaran sebesar 99,993\% dan pada tahun 2011sudah sangat efisien sebesar99.254 \% pada tahun 2012 efisiensinya sudah efisien juga yakni sebesar $99.637 \%$ dan pada tahun 2013-2014 efisiensi mengalami kesamaan yakni sebesar 99.995 dan rata- rata per tahun dari tahun 2009-2014 yakni sebesar $99.995 \%$ 
Tabel 19. Efisiensi Belanja Tidak Langsung Kabupaten Tanjung Jabung Timur

\begin{tabular}{|c|c|c|c|c|}
\hline Tahun & Target & Realisasi & $(\%)$ & Efisiensi \\
\hline 2009 & 202.041 & 202021 & 99,990 & Efisiensi \\
\hline 2010 & 269.258 & 269238 & 99,992 & Efisiensi \\
\hline 2011 & 277.042 & 277022 & 99,992 & Efisiensi \\
\hline 2012 & 305.433 & 305413 & 99,993 & Efisiensi \\
\hline 2013 & 322.880 & 322860 & 99,993 & Efisiensi \\
\hline 2014 & 341.809 & 341798 & 99.994 & Efisiensi \\
\hline \multicolumn{3}{|c|}{ Rata-rata } & 99.993 & Efisiensi \\
\hline
\end{tabular}

Sumber : statistik keuangan daerah provinsi Jambi 2013

Realisasi Belanja Tidak Langsung Kabupaten Tanjung Jabung Timur Realisasi Target Belanja Tidak Langsung tahun 2009-2014 target pencapaian belanja tidak langsung sudah mengalami efisien dari tahun ke tahun seperti tahun 2009 target realisasi pada tahun ini sebesar 99.990\% dan mengalami penurunan pada tahun 2010-2011 mengalami kesamaan jumlah efisiensi yakni sebesar $99.992 \%$ dan begitu juga pada tahun $2012-2013$ juga ada kesamaan dalam efisiensinya yakni sudah efisien yaitu sebesar $99.993 \%$ dan pada tahun 2014 jumlah efisiensinya sebesar $99.994 \%$ dan rata-rata efisiensinya sudah mengalami efisien yakni sebesar $99.993 \%$.

Tabel 20. Efisiensi Belanja Tidak Langsung Kabupaten Tebo

\begin{tabular}{|c|c|c|c|}
\hline Tahun & Target & Realisasi & (\%) Efisiensi \\
\hline 2009 & 185.121 & 187101 & 98,941 Efisiensi \\
\hline 2010 & 210.472 & 210452 & \begin{tabular}{l|l}
99,990 & Efisiensi
\end{tabular} \\
\hline 2011 & 267.974 & 267954 & \begin{tabular}{l|l}
99.536 & Efisiensi \\
\end{tabular} \\
\hline 2012 & 294.921 & 294901 & \begin{tabular}{l|l}
99,993 & Efisiensi
\end{tabular} \\
\hline 2013 & 341.223 & 341203 & \begin{tabular}{l|l}
99,994 & Efisiensi
\end{tabular} \\
\hline 2014 & 362.148 & 362128 & 99.477 Efisiensi \\
\hline \multicolumn{3}{|c|}{ Rata-rata } & 99.819 Efisiensi \\
\hline
\end{tabular}

Sumber :statistik keuangan daerah provinsi Jambi 2013

Efisiensi Belanja Tidak Langsung Kabupaten Tebo pencapainya target realisasinya pada tahun 2009-2014 setiap tahunnya mengalami perubahan dan pada tahun 2009 efisiensi belanja tidak langsung kabupaten batang hari sebesar $99.941 \%$ pada tahun 2010 sudah efisien juga dengan anggaran sebesar 99,990\% dan pada tahun 2011 sudah sangat efisien sebesar $99.535 \%$ pada tahun 2012 efisiensinya sudah efisien juga yakni sebesar $99.993 \%$ dan pada tahun 2013 sebesar 99.995 pada tahun 2014 sudah efisien juga yaitu sebesar $99.477 \%$ dan rata- rata per tahun dari tahun 2009-2014 yakni sebesar $99.819 \%$. 
Tabel 21.Efisiensi Belanja Tidak Langsung Kota Jambi

\begin{tabular}{|c|c|c|c|}
\hline Tahun Target & Realisasi & $(\%)$ & Efisiensi \\
\hline 381.497 & 381477 & 99,994 & Efisiensi \\
\hline 433.262 & 433242 & 99,995 & Efisiensi \\
\hline 489.881 & 489861 & 99,995 & Efisiensi \\
\hline 534.561 & 534541 & 99,996 & Efisiensi \\
\hline 638.773 & 638763 & 99,998 & Efisiensi \\
\hline 676.597 & 676577 & 99,997 & Efisiensi \\
\hline \multicolumn{2}{|c|}{ Rata-rata } & 99.995 & Efisiensi \\
\hline
\end{tabular}

Sumber :statistik keuangan daerah provinsi Jambi 2013

Realisasi Belanja Tidak Langsung Kota Jambi realisasi target Belanja Tidak Langsung tahun 2009-2014 target belanja tidak langsung sudah mengalami efisien dari tahun ke tahun seperti tahun 2009 target realisasi pada tahun ini sebesar $99.994 \%$ dan mengalami penurunan pada tahun 2010-2011 mengalami kesamaan jumlah efisiensi yakni sebesar $99.995 \%$ dan pada tahun 2012 yaitu sebesar $99.996 \%$ dan 2013 efisiensinya yakni sudah efisien yaitu sebesar $99.998 \%$ dan pada tahun 2014 jumlah efisiensinya sebesar $99.997 \%$ dan rata-rata efisiensinya sudah mengalami efisien yakni sebesar 99.995 $\%$.

Tabel 22. Efisiensi Belanja Tidak Langsung Kota Sungai Penuh

\begin{tabular}{|c|c|c|c|c|}
\hline Tahun & Target & Realisasi & $(\%)$ & Efisiensi \\
\hline 2009 & 69.312 & 69292 & 99.144 & Efisiensi \\
\hline 2010 & 184.207 & 184187 & 99.148 & Efisiensi \\
\hline 2011 & 219.598 & 219578 & 99.990 & Efisiensi \\
\hline 2012 & 229.977 & 229957 & 99.991 & Efisiensi \\
\hline 2013 & 264.044 & 264024 & 99.425 & Efisiensi \\
\hline 2014 & 219.621 & 219601 & 99.89 & Efisiensi \\
\hline \multicolumn{3}{|c|}{ Rata-rata } & 99.589 & Efisiensi \\
\hline
\end{tabular}

Sumber :statistik keuangan daerah provinsi Jambi 2013

Efisiensi Belanja Tidak Langsung Kota Sungai Penuh Tahun 2009-2014 dari tahun ke tahun sudah mengalami efisiensi dan malah dari target realisasi belanja tidak langsung efisiensinya bisa di bilang sudah sangat efisien dari kabupaten/kota di provinsi yang lain dapat kita lihat pada tahun 2009 sebesar $99.144 \%$ dan tahun 2010 sebesar $99.148 \%$ selanjutnya pada tahun 2011 sebesar $99.990 \%$ terlihat juga pada tahun 2012 yakni sebesar 99.991\% dan pada tahun 2013 yaitu sebesar $99.89 \%$ dan tahun 2014 sebesar $99.425 \%$ dan rata -rata efisiensi dari tahun 2009-2014 kota sungai penuh yaitu sebesar $99.98 \%$.

\section{SIMPULAN DAN SARAN}

\section{simpulan}

1. Perkembangan belanja tidak langsung kabupaten/kota di provinsi Jambi tahun 20092014 berdasarkan Rata-rata per tahun yakni tertinggi pada kabupaten Bungo sebesar $1.19 \%$ dan terendah pada kabupaten Tanjung Jabung Timur sebesar $0.11 \%$. 
2. Berdasarkan efisiensi belanja tidak langsung kabupaten/kota di provinsi Jambi pada tahun 2009-2014 dari rata-rata belanja tidak langsung target dari tahun ke tahun sudah mengalami peningkatan karena dari tahun 2009- 2014 seluruh kabupaten sudah efisien dari tahun ke tahun dalam mengelola belanja tidak langsung Kabupaten/Kota Di Provinsi Jambi pada Kota Sungai Penuh sudah sangat efektif dari Efisiensi Belanja Tidak Langsung .

\section{Saran}

Peneliti berikut dapat menambahkan periode waktu yang di gunakan yang lebih lengkap. Bagi pemerintah kabupaten/kota di provinsi Jambi khususnya pos belanja daerah agar lebih selektif lagi dalam mengeluarkan kas untuk belanja agardapat tercipta efektif dan efisien di lingkungan pemerintah Kabupaten/kota di propinsi Jambi.

Untuk mengatasi kekurangan atau kelebihan belanja tidak langsung sebaiknya pemerintah harus menetapkan standar ukuran atau patokan dalam mengambil kebijakan pembangunan agar terciptanya keseimbangan tersebut.

\section{DAFTAR PUSTAKA}

Andriana, Novia, 2011. Analisis Anggaran Pendapatan Belanja Daerah Terhadap Realisasi Tata Kelola Anggaran Pembangunan Di Sektor Pendidikan Pemerintah Kabupaten Jombang. Tesis Program Pascasarjana Fakultas Ekonomi Universitas Brawijaya.

Badan Pusat Statistik (2014) Provinsi Jambi dalam angka.

Darise, Nurlan, 2008. Pengelolaan Keuangan Pada Satuan Kerja Perangkat Daerah (SKPD). Penerbit PT Indeks. Jakarta.

Derise, Nurlan, 2009. Pengelolaan Keuangan Daerah. Cetakan 1. Edisi Kedua. PT Indeks. Kembangan-Jakarta Barat.

G.James dan M.Jhon, 2009. Prinsip-Prinsip manajemen keuangan, Edisi 13 buku 1, PT.Salemba empat. Jalan raya lentang agung NO.101-jakarta selatan.

Halim, Abdul, 2001. Manajemen Keuangan Daerah. Seri Bunga Rampai, Penerbit UPPAMP YKPN. Yogyakarta.

Halim, Abdul, 2007. Akuntansi Sektor Publik Akuntansi Keuangan Daerah. Edisi ke-3. Panerbit Salemba Empat. Jakarta.

Halim, Abdul, 2004. Akuntansi Sektor Publik, Akuntansi Keuangan Daerah.Edisi Revisi. Penerbit Salemba Empat. Jakarta.

Indriani, Hylina, 2011. Analisis Belanja Daerah Kabupaten Ngawi.

Jusmawati, 2012. Analisis Kinerja Keuangan Daerah Pemerintah Kabupaten Soppeng terhadap Efisiensi Pendapatan Asli Daerah. Skripsi. Jurusan Manajemen. Fakultas Ekonomi dan Bisnis. Universitas Hasanuddin.

Keputusan Menteri Dalam Negeri Nomor 29 Tahun 2002 tentang Pedoman Pengurusan, Pertanggungjawaban dan Pengawasan Keuangan Daerah, serta Tata Cara Penyusunan Anggaran Pendapatan dan Belanja Daerah, Pelaksanaan Tata Usaha Keuangan Daerah serta Penyusunan Perhitungan Anggaran Pendapatan dan Belanja Daerah.

Mahmudi, 2010. Manajemen Keuangan Daerah. Erlangga. PT Gelora Aksara Pratama : Yogyakarta.

Nofriza, Eri, 2012. Pengaruh Pengeluaran Pemerintah Atas Pendidikan terhadap Pertumbuhan Ekonomi Di Kabupaten Sarolangun Tahun 2001-2010. Skripsi Fakultas Ekonomi. Universitas Jambi Kampus Sarolangun. 
Patilima hamid, 2013, metode penelitian kualitatif. Alfaberta, cv jl gegerkalong hilit bandung.

Renyowijoyo, Muindro, 2010. Akuntansi Sektor Publik : Oranisasi Non Laba. Edisi ke 2. Penerbit Mitra Wacana Media. Jakarta.

Ritonga, 2009. Perencanaan dan Penganggaran Keuangan Daerah di Indinesia. Penerbit Sekolah Paskasarjana UGM. Yogyakarta.

Riza Yulita,(2013), analisis komponen belanja daerah terhadap total belanja daerah, yulita riza kabupaten merangin tahun 2007-2011 skripsi. Jurusan keuangan daerah. Fakultas ekonomi dan bisnis. Iniversitas jambi kampus sarolangun.

Suparmoko.M, 2003, keuangan negara dalam teori dan praktek. BPFE.yogyakarta

Statistik keuangan daerah Provinsi Jambi 2013. http, ://jambi.bps.go.id

Tanjung A, 2009. Penata Usahaan dan Akuntansi Keuangan Daerah. Selemba Empat : Jakarta.

Undang-Undang Nomor 32 Tahun 2004 tentang perimbangan keuangan antara pemerintah pusat dan daerah, Republik Indonesia.

Undang-Undang Nomor 33 Tahun 2004 tentang Perimbangan Keuangan Antara Pemerintah Pusat dan Daerah, Republik Indonesia.

Widjaja Haw, 2005. Penyelenggaraan Otonomi di Indonesia : Dalam Rangka Sosialisasi UU No. 32 Tahun 2004 Tentang Pemerintah daerah. PT Raja Grafindo Persada : Jakarta

Widjaja, Haw, 2009. Otonomi Daerah dan Daerah Otonom. Penerbit Rajawali Pers. Jakarta.

Yani, Ahmad, 2009. Hubungan Keuangan Antara Pemerintah Pusat dan Daerah di Indonesia. Penerbit PT Raja Grapindo Persada. Jakarta. 